\section{Release of Non-Esterified Fatty Acids from Adipose Tissue in Normal and Diabetic Rats}

From a number of recent papers it appears that the mobilization and transport of fat from fat depots to sites of its further utilization take place mostly in the form of non-esterified fatty acids ${ }^{1}$. Evidence that this is so is provided by Dole ${ }^{2}$ and Gordon ${ }^{3}$ who observed during states with an inadequate utilization of carbohydrates an elevated blood level of non-esterified fatty acid. When the utilization of carbohydrates was increased (after ingestion of glucose or after administration of insulin) the blood level of non-esterified fatty acids decreased. Experiments with adipose tissue in vitro also confirmed that under certain conditions non-esterified fatty acids can be released. The amount released depends on whether at the moment the animal was killed the energy requirements were satisfied from reserves. Gordon and Cherkes ${ }^{4}$ have demonstrated an inereased release of non-esterified fatty acids from incubated epididymal fat of fasting rats, while during satiety the release was insignificant. It was also revealed that the release of non-esterified fatty acids from incubated adipose tissue of normal animals is increased by various hormones added in vitro: adrenalin ${ }^{4}$, noradrenalin, corticotropin $^{5,6}$, while its release is arrested after the addition of insulin 4 . Thus, it can be assumed that the adipose tissue of diabetic animals, which must mobilize fat reserves, will also, in vitro, release more non-esterified fatty acids than the tissue of healthy animals. Our experiments confirm this assumption.

For our experiments we used intact white rats and rats with alloxan diabetes weighing $100-120 \mathrm{gm}$. The animals were killed after 16 hours fasting and a slice of about $50 \mathrm{mgm}$. of epididymal fat was incubated for four hours in $4 \mathrm{ml}$. of pooled post-absorptive human serum at $37^{\circ} \mathrm{C}$. with constant agitation. The initial and final concentration of non-esterified fatty acids in the medium was estimated using Dole's method ${ }^{2}$, the blood sugar level by Hagedorn and Jensen's method. The results are expressed in micro-equivalents of non-esterified fatty acids released after 1 hour per $1 \mathrm{gm}$. of fresh tissue \pm standard error.

We performed two separate experiments under the same conditions. In the first experiment, however, we used diabetic rats 8 days after the administration of alloxan, in the second experiment rats 15 days after the administration of alloxan, the human serum used as medium being from a different group of donors. From the tissue of the control animals in the first experiment $2.32+0.31$ uequiv. non-esterified fatty acids were released during the incubation, while in the diabetic rats the corresponding figure was $4.67 \pm 0.41$ kequiv. In the second experiment we obtained the following results: control animals $5.21 \pm 0.51 \mu$ equiv. non-esterified fatty acids, diabetic animals $8.58 \pm 0.52 \mu$ equiv. non-esterified fatty acids. The blood sugar level of the diabetic rats was $170-340$ mgm. per cent immediately before the beginning of the experiment, of the control animals 70-110 mgm. per cent. The results are shown in Table 1.

From these experiments it appears that in animals with alloxan diabetes the release of non-esterified fatty acids from the adipose tissue is significantly higher. In earlier experiments we established the direct correlation between non-esterified fatty acids' level and blood sugar level in diabetic animals?. In the experiments carried out during the present work,

$$
\begin{aligned}
& \begin{array}{l}
\text { Table 1. NON-ESTERIFIED FATTY ACIDS RELEASED From FatTy } \\
\text { TISSUE OF NORYAL AND ALLOXAN DIABETIC RATS }
\end{array}
\end{aligned}
$$

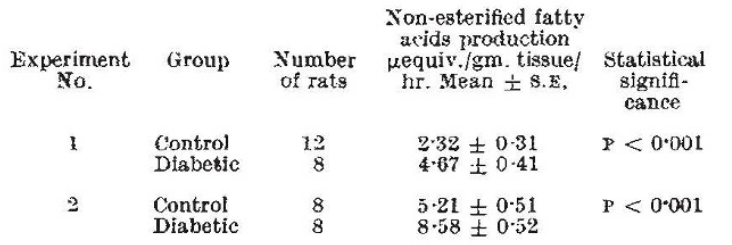

however, no relation between the release of nonesterified fatty acids from the tissue and the blood sugar level in the alloxan diabetic animals was confirmed. To elucidate the mechanism of the difference of nonesterified fatty acids, release from adipose tissue in normal and alloxan diabetic rats it will be necessary to direct attention to changes in the tissue lipoprotein lipase activity; this being the object of our current work.

J. WENKEOVÁ

$$
\text { J. PÁv }
$$

Institut of Human Nutrition, Budĕjovická 800 Prague 14.

${ }^{1}$ Fredrickson, D. S., and Gordon, R. S., Jun., Physiol. Ree', 38, 585 (1958) 2 Dole, V. P., J. Clin. Invest., 35, 150 (1956).

${ }^{8}$ Gordon, R. S., Jun., and Cherkes, A., J. Clin. Invest., 35, 206 (1956) Gordon, 1R. S., jun., Cherkes, A., idem., Proc. Soc. Exp. Biol. Med., 97 150 (1958).

5 White, J. E., and Engel, F. L., J. Clin. Inrest, 37, 942 (1958).

Idem., ibid., 37, 1556 (1958)

Wenke, M., Wenkeová, J., Skrobal, D., Mühlbachová, F., aud Zita, C. Acta Univ. Carolinae-Medica, 1-3, 462 (1958).

\section{Distribution of Enzyme Systems Responsible for Steroid Metabolism in Different Tissues and Subcellular Fractions}

From their studies of the in vivo metabolism of various biologically active and inactive 11-oxygenated steroids, Bush and Mahesh ${ }^{1}$ believe that the glucocorticoid activity of these steroids is due to the specific interaction of an 11 $\beta$-hydroxy group on the steroid molecule with the receptor sites for such hormones, and that such an interaction does not involve oxidation-reduction at $\mathrm{C}-\mathrm{I1}$. However, Talalay and co-workers ${ }^{2}$ observed that various hydroxy-steroids, including the 11-oxygenated ones, can act as coenzymes in the transfer of hydrogen between pyridine nucleotides in the presence of suitable steroid dehydrogenases and they suggest that this is the mode of action of steroid hormones. In the present study, the metabolism of cortisol and cortisone has been investigated in various tissues in order to determine the distribution of enzyme systems responsible for the metabolism of the steroids, with the view of finding out whether steroid metabolism is directly involved in hormone action or whether it represents stages in their detoxication and removal from the body.

The diaphragm of the unfasted male albino rat was the first tissue to be studied. One gram of the tissue was incubated with $100 \mu \mathrm{gm}$. of cortisol in $10 \mathrm{ml}$. of Krebs-Ringer-phosphate buffer $(p \mathbf{H} 7 \cdot 0-7 \cdot 1)$ at $37 \cdot 4^{\circ} \mathrm{C}$. for two hours in an atmosphere of 100 per cent oxygen, and the steroids were extracted and then chromatographed on paper according to the methods described by Bush and Mahesh ${ }^{3}$ with minor modifications.

Steroid metabolites were detected and estimated using blue tetrazolium reagent for $\alpha$-ketolic compounds, 